\title{
Pengaruh Metode Cooperative Type Jigsaw Terhadap Peningkatan Hasil Belajar Siswa Mata Pelajaran Pendidikan Agama Islam Di Kelas V Madrasah Ibtidaiyah Muhammadiyah 09 Kranji Lamongan
}

\author{
M. Chotibuddin \\ Sekolah Tinggi Ilmu Tarbiyah Muhammadiyah Paciran Lamongan, Indonesia
}

Abstract: Learning and teaching are the most important activities in the whole educational process. This implies that the success or failure of the educational goals depends on how to design the teaching and learning process (learning) professionally. The success of the learning process cannot be separated from the preparation of students and the preparation of educators. In learning activities, methods are needed for educators and their use varies according to the goals to be achieved after teaching ends. An educator will not be able to carry out his duties if he does not master any of the teaching methods that have been formulated. The methods used in data collection are the observation method and the test method. The data analysis used was the instrument validity test, the normality test and the homogeneity test. The results of the research carried out proved that student learning outcomes before and after using the jigsaw method could be seen from the average pre-test scores of 62.00 and 76.60 post-test results. The pre-test result value is lower than the post-test score, so it means that there are differences in student learning outcomes before and after using the jigsaw method in the learning process.

The percentage of the completeness criteria of the pre-test result value is $28 \%$, while the posttest result score is $68 \%$. From this data, it can be seen that using the jigsaw method can affect student learning outcomes. Hypothesis testing using the Product Moment Correlation test and Paired Sample T-test with the help of SPSS 20 software in the sig (2-tailed) section is known to be $0.000<0.05$. As the basis for decision making in the Product Moment Correlation test and decision guidelines based on the probability value, it can be concluded that HO is rejected and $\mathrm{Ha}$ is accepted. This means that the jigsaw method can affect the improvement of learning outcomes of class V Islamic Religious Education at MI Muhammadiyah 09 Kranji Lamongan

Keywords: Cooperative Type Jigsaw Method, Student learning outcomes

\section{Pendahuluan}

Pendidikan memegang peranan penting dan tidak dapat dipisahkan dari kehidupan, sifatnya mutlak baik dalam kehidupan seseorang, keluarga, bangsa atau negara. Pendidikan bagi suatu bangsa merupakan suatu kebutuhan dasar yang harus dipenuhi untuk meningkatkan kualitas sumber daya manusia sesuai dengan UU nomor 20 tahun 2003 Bab 1 Pasal 1 No. 1, yang berbunyi: "Pendidikan adalah usaha sadar dan terencana untuk mewujudkan suasana belajar dan proses pembelajaran agar peserta didik secara aktif mengembangkan potensi dirinya untuk memiliki kekuatan spiritual, keagamaan, pengendalian diri, kepribadian, kecerdasan, akhlaq mulia, serta keterampilan yang diperlukan dirinya, masyarakat, bangsa, dan negara. 


\section{Chotibuddin}

Islam juga mendorong pendidikan sejak Al-Qur'an diturunkan, hal tersebut dibuktikan dengan firman Allah SWT. yang berbunyi:

Artinya:" Wahai orang-orang yang beriman! Apabila dikatakan kepadamu, "Berilah kelapangan di dalam majelis-majelis," maka lapangkanlah, niscaya Allah akan memberi kelapangan untukmu. Dan apabila dikatakan, "Berdirilah kamu," maka berdirilah, niscaya Allah akan mengangkat (derajat) orang-orang yang beriman di antaramu dan orang-orang yang diberi ilmu beberapa derajat. Dan Allah Maha Mengetahui terhadap apa yang kamu kerjakan" (Q.S. AlMujadalah: 11).

Dengan ilmu pengetahuan seorang hamba akan mendapatkan tempat yang mulia, hal tersebut diterangkan berkali-kali di dalam Al-Qur'an betapa pentingnya pendidikan, tanpa pendidikan tidak ada pengetahuan dan tanpa pengetahuan niscaya kehidupan manusia akan menjadi sengsara. Ilmu pengetahuan merupakan bekal utama manusia dalam menapaki perjalanan hidupnya. Al-Qur'an memposisikan manusia yang mempunyai pengetahuan pada derajat yang lebih tinggi.

Belajar dan mengajar merupakan kegiatan yang paling utama dalam keseluruhan proses pendidikan. Ini mengandung arti bahwa berhasil atau gagalnya target tujuan pendidikan sangat tergantung kepada bagaimana merancang proses belajar mengajar (pembelajaran) dengan profesional. Keberhasilan proses pembelajaran tidak terlepas dari persiapan peserta didik dan persiapan oleh tenaga pendidik.

Guru merupakan elemen penting dalam setiap aktivitas belajar dan mengajar. Oleh karena itu, seorang guru atau pendidik dituntut menjadi guru yang efektif dalam memberikan materi pelajaran kepada siswa. Seperti merancang menggunakan metode dalam proses pembelajaran.

Berdasaran pada perencanaan pembelajaran, setiap komponen mempunyai ketergantungan dengan tujuan. Metode perencanaan pembelajaran juga ditentukan oleh tujuan yang hendak dicapai. Dalam kegiatan pembelajaran, metode diperlukan untuk pendidik dan penggunaannya bervariasi sesuai dengan tujuan yang ingin dicapai setelah pengajaran berakhir. Seorang pendidik tidak akan dapat melaksanakan tugasnya jika ia tidak menguasai satupun metode mengajar yang telah dirumuskan.

Pelajaran Pendidikan Agama Islam merupakan pelajaran yang menekankan pada pemahaman agama Islam dan juga ajaran-ajaran yang terkandung di dalamnya. Dalam mempelajari Pendidikan Agama Islam ini diharapkan agar para pemeluk agama Islam semakin 
mendalami agama tersebut seperti menumbuhkan rasa percaya kepada Allah Swt. dan mempraktikkan apa yang tertera di dalam proses pembelajaran tersebut seperti beribadah, dan juga mengaplikasikannya ke dalam kehidupan sehari-hari.

Dari uraian di atas dapat diasumsikan bahwa mata pelajaran Pendidikan Agama Islam mempunyai nilai yang sangat strategis dan penting dalam mempersiapkan sumber daya manusia yang unggul, handal, dan bermoral sejak dini.

Pada masa ini, murid banyak yang mengeluh bosan dengan proses pembelajaran Pendidikan Agama Islam. Jika diamati murid bosan disebabkan oleh banyak hal, namun yang paling menonjol adalah karena proses pembelajaran hanya sebatas cerita dan tugas, sehingga mereka tidak bisa menangkap apa yang disampaikan oleh pendidik dan juga membuat mereka tidak tertarik untuk mempelajari mata pelajaran Pendidikan Agama Islam. Masih jarang ada guru yang bisa menerapkan bermacam-macam metode saat proses pembelajaran, seringnya mereka hanya menggunakan metode ceramah dan cerita. Padahal dalam kurikulum 2013 di tekankan bahwa murid harus lebih aktif dari pada guru.

Berdasarkan latar belakang masalah di atas maka penulis merumuskan judul penelitian"Pengaruh Metode Cooperative Type Jigsaw Terhadap Peningkatan Hasil Belajar Siswa Mata Pelajaran Pendidikan Agama Islam di Kelas V MI Muhammadiyah 09 Kranji Lamongan.

\section{Rumusan Masalah}

Berdasar latar belakang di atas, maka dapat dirumuskan masalah sebagai berikut:

1. Bagaimana penerapan Metode jigsaw pada proses pembelajaran Mata Pelajaran PAI pada siswa kelas V MI Muhammadiyah 09 Kranji Lamongan?

2. Bagaimana Pengaruh Metode jigsaw terhadap peningkatan Hasil Belajar Siswa Pada Mata Pelajaran PAI Kelas V MI Muhammadiyah 09 Kranji Lamongan?

\section{Landasan teori}

\section{Hasil Belajar}

Hasil belajar merupakan "penguasaan pengetahuan atau keterampilan yang dikembangkan melalui mata pelajaran, lazimnya ditunjukkan dengan nilai tes atau angka nilai yang telah diberikan oleh para guru. 


\section{Chotibuddin}

Hasil belajar siswa pada hakikatnya adalah perubahan tingkah laku yang telah terjadi melalui proses pembelajaran. Perubahan tingkah laku tersebut berupa kemampuan-kemampuan siswa setelah aktifitas belajar yang menjadi hasil perolehan belajar. Dengan demikian hasil belajar adalah perubahan yang terjadi pada individu setelah mengalami pembelajaran.

Pengertian tentang hasil belajar diatas juga dipertegas oleh Nawawi yang menyatakan bahwa hasil belajar dapat diartikan sebagai tingkat keberhasilan siswa dalam mempelajari materi pelajaran di sekolah yang dinyatakan dalam skor yang diperoleh dari hasil tes mengenal sejumlah materi pelajaran tertentu.

Dari penjelasan di atas, dapat dinyatakan bahwa hasil belajar adalah proses perubahan perilaku siswa setelah mengikuti kegiatan pembelajaran dengan tujuan tertentu. Artinya tujuan kegiatan belajar mengajar ialah perubahan tingkah laku, baik yang menyangkut pengetahuan, keterampilan, sikap, bahkan meliputi segenap aspek pribadi.

\section{Macam-Macam Hasil Belajar}

Menurut Bloom dan kawan-kawan, membagi hasil belajar menjadi tiga dominan, yaitu:

1) Hasil Belajar Kognitif

Menilai kemampuan otak dan penalaran siswa atau pemahaman, pengetahuan, hafalan, analisis, ingatan, dan penerapan siswa.

2) Hasil Belajar Afektif

Menilai perhatian siswa terhadap pelajaran, disiplin dalam belajar, kebiasaan belajar, motivasi, emosi, dan kerjasama dari setiap peserta didik atau siswa.

\section{3) Hasil Belajar Psikomotorik}

Menilai dari bentuk kemampuan bertindak setelah siswa tersebut menerima pengalaman belajar, dan menilai keterampilan siswa.

\section{Pengertian Metode Pembelajaran}

Metode berasal dari bahasa Yunan "metodhos" yang berarti cara atau jalan yang ditempuh. Jadi, metode adalah suatu cara yang digunakan untuk mencapai tujuan yang telah ditetapkan.

Sudjana mengemukakan bahwa metode pembelajaran adalah cara yang digunakan oleh pendidik dalam mengadakan hubungan dengan peserta didik pada saat berlangsung pembelajaran. Dengan kata lain, metode ini digunakan dalam konteks pendekatan secara personil antara pendidik dan peserta didik supaya peserta didik tertarik dan menyukai dengan materi yang 
diajarkan. Suatu pelajaran tidak akan pernah berhasil jika tingkat antusias peserta didik berkurang.

Sedangkan menurut Gagne pembelajaran didefinisikan sebagai " $a$ set of events embedded in purpuseful activities that facilitate learning". Pembelajaran adalah serangkaian aktivitas yang sengaja diciptakan dengan maksud untuk memudahkan terjadinya proses belajar.

Pembelajaran dapat diartikan sebagai proses kerja sama antara guru dan siswa dalam memanfaatkan segala potensi dan sumber yang ada baik potensi yang bersumber dari dalam diri siswa itu sendiri seperti minat, bakat dan kemampuan dasar yang dimiliki termasuk gaya belajar maupun potensi yang ada di luar diri siswa seperti lingkungan, sarana dan sumber belajar sebagai upaya untuk mencapai tujuan belajar tertentu.

\section{Pengertian Pendidikan Agama Islam}

Pendidikan Agama Islam merupakan pelajaran yang menekankan pada pemahaman agama Islam dan juga ajaran-ajaran yang terkandung di dalamnya.

Menurut Armai Arief Pendidikan Agama Islam yaitu sebuah proses yang dilakukan untuk menciptakan manusia-manusia yang seutuhnya; beriman dan bertaqwa kepada Tuhan serta mampu mewujudkan eksistensinya sebagai khalifah Allah di muka bumi, yang bersandar kepada ajaran Al-Qur'an dan Sunnah, maka tujuan dalam konteks ini berarti terciptanya insan-insan kamil setelah proses berakhir.

Dalam mata pelajaran Pendidikan Agama Islam ini peserta didik dituntut untuk mengenal, memahami, menghayati, dan mengimani ajaran agaa Islam, dibarengi dengan tuntunan untuk menghargai penganut agama lain dalam hubungannya dengan kerukunan antar umat beragama.

\section{Tujuan Pendidikan Agama Islam}

Pendidikan Agama Islam bertujuan untuk menumbuhkan serta meningkatkan keimanan melalui pemupukan pengetahuan, penghayatan, pengamalan, serta pengalaman peserta didik tentang agama Islam sehingga menjadi manusia yang terus berkembang dalam hal keimanan dan ketaqwaannya. 


\section{Chotibuddin}

\section{Metode Penelitian}

\section{Metode Observasi}

Observasi merupakan teknik pengamatan dan pencatatan mengenai fakta tentang obyek yang sedang diteliti. Observasi dilakukan untuk menemukan informasi dari suatu kejadian atau peristiwa secara sistematis dan didasarkan pada tujuan penelitian yang telah dirumuskan.

Dengan menggunakan teknik ini, penulis dapat mengamati obyek yang hendak dijadikan tempat penelitian yaitu MI Muhammadiyah 09 Kranji Lamongan . Dimana peneliti melakukan pengamatan langsung untuk memperoleh data tentang letak geografis, sarana prasarana, dan kegiatan pembelajaran.

Penulis menyajikan hasil observasi dalam tabel, dan rumus persentase nilai perolehan sebagai berikut:

$$
\text { Persentase Nilai Perolehan } \quad=\frac{\text { Jumlah Skor }}{\text { Skor Maksimal }} \times 100 \%
$$

Dengan taraf keberhasilan yang ditetapkan yaitu:
a. $86 \% \leq \mathrm{NR} \leq 100 \%$ : Sangat Baik
b. $71 \% \leq \mathrm{NR} \leq 85 \%$ : Baik
c. $55 \% \leq \mathrm{NR} \leq 70 \% \quad$ : Cukup Baik
d. $0 \% \leq \mathrm{NR} \leq 55 \% \quad$ : Cukup

\section{Metode Tes}

Tes merupakan serentetan pertanyaan atau latihan soal yang digunakan untuk mengukur pengetahuan siswa. Sehingga dalam penelitian ini, penulis menggunakan Pre-Test dan Post-Test.

Pre-Test yaitu bentuk pertanyaan yang diberikan guru kepada muridnya sebelum memulai pelajaran. Pertanyaan itu biasanya dilakukan guru diawal pembukaan pelajaran. Dengan tujuan untuk mengetahui apakah ada salah satu diantara murid sudah mengetahui mengenai materi yang akan diajarkan.

Post-test merupakan bentuk pertanyaan yang diberikan setelah materi pembelajaran selesai. Adapun tujuan diadakannya post-test adalah untuk memperoleh data tentang hasil yang dicapai oleh siswa setelah mengikuti proses pembelajaran. Hasil post-test dari kelompok eksperimen akan dibandingkan dengan hasil post-tes kelompok kontrol, sehingga akan diketahui seberapa jauh Metode Think Pair and Share dapat mempengaruhi hasil belajar siswa.

\section{Teknik Analisis Data}


Dalam penelitian kuantitatif, analisis data merupakan kegiatan setelah data dari seluruh responden atau sumber data lain terkumpul. Kegiatan dalam analisis data adalah: mengelompokkan data berdasarkan variabel dan jenis responden, mentabulasi data berdasarkan variabel dari seluruh responden, menyajikan data tiap variabel yang diteliti, melakukan perhitungan untuk menguji hipotesis yang telah diajukan.

\section{Uji Instrumen}

Uji Validitas

Uji validitas digunakan untuk mengukur sah atau tidaknya suatu soal. Menurut Arikunto menyatakan bahwa validitas adalah suatu ukuran yang menunjukkan tingkat kendala atau kesalahan suatu alat ukur yang kurang valid, maka memiliki validitas yang rendah.

Suatu soal akan dinyatakan valid jika pertanyaan pada soal tersebut dapat mengungkapkan data yang ingin diperoleh. Untuk melakukan uji vaditas ini peneliti menggunakan Microsoft Excel, dengan rumus:

$$
\mathrm{r}_{\mathrm{xy}}=\frac{N \sum X Y-\left(\sum X\right)\left(\sum Y\right)}{\sqrt{\left(N \sum X^{2}-\left(\sum X\right)^{2}\right)\left(N \sum Y^{2}-\left(\sum Y\right)^{2}\right)}}
$$

Keterangan:

$\mathrm{r}$ : Koefisien korelasi antara variabel $\mathrm{X}$ dan $\mathrm{Y}$

$\Sigma \mathrm{X}$ : Jumlah skor dalam distribusi $\mathrm{X}$

$\Sigma \mathrm{Y}$ : Jumlah skor dalam distribusi $\mathrm{Y}$

$\mathrm{n} \quad$ : Banyaknya responden

berdasarkan pada hasil uji instrumen melalui perhitungan dengan Microsoft Excel dapat diperoleh bahwa seluruh item soal dinyatakan valid (untuk skor dan hasil validitas terlampir).

Untuk mengetahui skor maksimal dapat dihitung dengan rumus: $\frac{\text { Skor }}{\text { nilai maksimal }} \times 100$

\section{Uji Prasyarat Analisis}

Sebelum melakukan uji hipotesis dilakukan beberapa uji prasyarat statistik untuk menentukan rumus statistik yang akan digunakan dalam uji hipotesis tersebut. Uji prasyarat analisis terdiri dari uji normalitas dan uji homogenitas.

a. Uji Normalitas 


\section{Chotibuddin}

Uji normalitas dilakukan dengan menggunakan rumus one sample $K S$ yang dilakukan dengan kaidah Asymp sig atau nilai P. Proses perhitungan normalitas ini menggunakan bantuan software SPSS versi 20 untuk mengetahui sebaran data terdistribusi normal atau tidak. Sebuah syarat data berdistribusi normal apabila nilai signifikansi yang diperoleh dari hasil perhitungan lebih besar dan dari tingkat alpha 5\% (sig. (2-tailed) $>0.05$ ). Jika nilai signifikansi yang diperoleh dari hasil perhitungan lebih kecil dari tingkat alpha 5\% (sig. (2tailed) $<0.05)$, maka data tersebut berdistribusi tidak normal.

b. Uji Homogenitas

Uji homogenitas digunakan untuk menguji apakah kedua data tersebut homogen atau tidak (heterogen) yaitu dengan cara membandingkan kedua variansnya. Pengujian homogenitas peneliti menggunakan software SPSS 20 dengan Test of Homogenity of Variance. Dengan ketentuan jika nilai signifikansi hitung lebih besar dari taraf signifikansi 0,05 (5\%) maka skor hasil tes tersebut tidak memiliki perbedaan varian atau homogen.

\section{Uji Hipotesis}

Setelah dilakukan uji normalitas dan homogenitas, kemudian dilakukan uji hipotesis dengan menggunakan Uji Paired Sample T-test dan Uji korelasi Product moment.

\section{a. Uji Paired Sample T-test}

Uji Paired sample T-test dilakukan terhadap dua sampel yang berpasangan (paired). Sampel yang berpasangan diartikan sebagai sebuah sampel dengan subjek yang sama namun mengalami dua instruksi atau pengukuran yang berbeda. Dalam penelitian ini terdiri dari dua sampel yang berhubungan atau berpasangan satu dengan yang lainnya, yaitu sampel sebelum diberi perlakuan dan sampel yang sudah diberi perlakuan dengan metode jigsaw. Uji Paired Sample T-test hasil data pretest dan posttest dianalisis dengan menggunakan bantuan software Statistical Package For Sosial Sciences (SPSS) 20 for windows. Dengan pedoman keputusan berdasarkan nilai probabilitas:

1) Jika probabilitas $>0,05$, maka $\mathrm{H}_{0}$ diterima

2) Jika probabilitas $<0,05$, maka $\mathrm{H}_{0}$ ditolak

\section{b. Uji korelasi Product moment}

Untuk menganalisis hubungan kausal antara variabel bebas dan terikat dalam penelitian ini adalah dengan menggunakan uji korelasi product moment.

Hipotesis yang hendak diuji dalam penelitian ini, yaitu: 
$\mathrm{H}_{0}$ : Tidak terdapat pengaruh metode Cooperative Type Jigsaw terhadap hasil belajar siswa pada mata pelajaran Pendidikan Agama Islam di kelas V MI Muhammadiyah 09 Kranji Lamongan tahun pelajaran 2019/2020.

$\mathrm{H}_{\mathrm{a}}$ : Terdapat pengaruh metode Cooperative Type Jigsaw terhadap hasil belajar siswa pada mata pelajaran Pendidikan Agama Islam di kelas V MI Muhammadiyah 09 Kranji Lamongan tahun pelajaran 2019/2020.

Peneliti melakukan pengujian hipotesis menggunakan SPSS 20 dengan uji korelasi product moment. Adapun dasar pengambilan keputusan dalam uji korelasi product moment adalah:

a) Jika $r$ hitung > $r$ tabel, maka $\mathrm{H}_{0}$ ditolak dan $\mathrm{H}_{\mathrm{a}}$ diterima.

b) Jika $r$ hitung < $r$ tabel, maka $\mathrm{H}_{0}$ diterima dan $\mathrm{H}_{\mathrm{a}}$ ditolak.

\section{Penyajian data}

Metode Observasi

Observasi merupakan teknik pengamatan dan pencatatan mengenai fakta tentang obyek yang sedang diteliti. Berdasarkan hasil observasi melalui lembar observasi maka di peroleh hasil sebagai berikut :

$$
\begin{array}{ll}
\text { Persentase Nilai Perolehan } & =\frac{\text { Jumlah Skor }}{\text { Skor Maksimal }} \times 100 \% \\
\text { Persentase Nilai Perolehan } & =\frac{36}{45} \times 100 \% \\
& =80 \%
\end{array}
$$

Taraf Keberhasilan yang ditetapkan yaitu:
a. $86 \% \leq \mathrm{NR} \leq 100 \%$ : Sangat Baik
b. $71 \% \leq \mathrm{NR} \leq 85 \%$ : Baik
c. $55 \% \leq \mathrm{NR} \leq 70 \% \quad$ : Cukup Baik
d. $0 \% \leq \mathrm{NR} \leq 55 \% \quad$ : Cukup

Metode Tes

Tes merupakan serentetan pertanyaan atau latihan soal yang digunakan untuk mengukur pengetahuan siswa. Sehingga dalam penelitian ini, penulis menggunakan Pre-Test dan Post-Test.

Selanjutnya guru melakukan pre-test kepada siswa dengan memberikan teks soal. Hasil dari nilai pre-test siswa dapat dilihat pada Tabel berikut: 
Tabel: Nilai Hasil Pre-Test

\begin{tabular}{|l|l|c|c|c|c|c|}
\hline No. & \multicolumn{1}{|c|}{$\begin{array}{c}\text { Nama } \\
\text { Siswa }\end{array}$} & $\begin{array}{c}\text { Nilai } \\
\text { Pre-test }\end{array}$ & Keterangan & $\begin{array}{c}\text { Nilai } \\
\text { postes }\end{array}$ & KKM & Keterangan \\
\hline 1. & A & 45 & Tidak Tuntas & 65 & 75 & Tidak Tuntas \\
\hline 2. & B & 75 & Tuntas & 90 & 75 & Tuntas \\
\hline 3. & C & 45 & Tidak Tuntas & 65 & 75 & Tidak Tuntas \\
\hline 4. & D & 60 & Tidak Tuntas & 75 & 75 & Tuntas \\
\hline 5. & E & 70 & Tidak Tuntas & 75 & 75 & Tuntas \\
\hline 6. & F & 50 & Tidak Tuntas & 85 & 75 & Tuntas \\
\hline 7. & G & 75 & Tuntas & 85 & 75 & Tuntas \\
\hline 8. & H & 65 & Tidak Tuntas & 65 & 75 & Tidak Tuntas \\
\hline 9. & I & 70 & Tidak Tuntas & 80 & 75 & Tuntas \\
\hline 10. & J & 50 & Tidak Tuntas & 75 & 75 & Tuntas \\
\hline 11. & K & 55 & Tidak Tuntas & 75 & 75 & Tuntas \\
\hline 12. & L & 65 & Tidak Tuntas & 75 & 75 & Tuntas \\
\hline 13. & M & 80 & Tuntas & 95 & 75 & Tuntas \\
\hline 14. & N & 60 & Tidak Tuntas & 65 & 75 & Tidak Tuntas \\
\hline 15. & O & 70 & Tidak Tuntas & 85 & 75 & Tuntas \\
\hline 16. & P & 50 & Tidak Tuntas & 70 & 75 & Tidak Tuntas \\
\hline 17. & Q & 85 & Tuntas & 90 & 75 & Tuntas \\
\hline 18. & R & 55 & Tidak Tuntas & 80 & 75 & Tuntas \\
\hline 19. & S & 20 & Tidak Tuntas & 40 & 75 & Tidak Tuntas \\
\hline 20. & T & 40 & Tidak Tuntas & 60 & 75 & Tidak Tuntas \\
\hline 21. & U & 65 & Tidak Tuntas & 90 & 75 & Tuntas \\
\hline 22. & V & 75 & Tuntas & 80 & 75 & Tuntas \\
\hline 23. & W & 70 & Tidak Tuntas & 80 & 75 & Tuntas \\
\hline 24. & X & Tuntas & 80 & 75 & Tuntas \\
\hline 25. & Y & & 90 & 75 & Tuntas \\
\hline & & & & & \\
\hline
\end{tabular}

\section{Data Hasil Observasi}

Adapun data hasil observasi yang dilaksanakan oleh peneliti setiap hari senin pada tanggal 15 Juli - 13Agustus.

Tabel: Hasil Observasi Kegiatan Pembelajaran Menggunakan Metode Jigsaw

\begin{tabular}{|c|c|c|c|c|c|}
\hline Aspek Yang Diamati & \multicolumn{5}{|c|}{ Kategori Skor } \\
\hline & $\mathbf{5}$ & $\mathbf{4}$ & $\mathbf{3}$ & $\mathbf{2}$ & $\mathbf{1}$ \\
\hline 1 & $\sqrt{ }$ & & & & \\
\hline 2 & & $\sqrt{ }$ & & & \\
\hline 3 & & & $\sqrt{ }$ & & \\
\hline 4 & & $\sqrt{ }$ & & & \\
\hline 5 & & & $\sqrt{ }$ & & \\
\hline
\end{tabular}




\begin{tabular}{|c|c|c|c|c|c|}
\hline 6 & & $\sqrt{ }$ & & & \\
\hline 7 & & $\sqrt{ }$ & & & \\
\hline 8 & $\sqrt{ }$ & & & & \\
\hline 9 & & $\sqrt{ }$ & & & \\
\hline Jumlah Skor & $\mathbf{1 0}$ & $\mathbf{2 0}$ & $\mathbf{6}$ & - & - \\
\hline
\end{tabular}

Persentase Nilai Perolehan

$$
\begin{aligned}
& =\frac{\text { Julah Skor }}{\text { Skor Maksimal }} \times 100 \% \\
& =\frac{36}{45} \times 100 \% \\
& =80 \%
\end{aligned}
$$

Taraf Keberhasilan yang ditetapkan yaitu:

1. $86 \% \leq \mathrm{NR} \leq 100 \%$ : Sangat Baik

2. $71 \% \leq \mathrm{NR} \leq 85 \% \quad$ : Baik

3. $55 \% \leq \mathrm{NR} \leq 70 \% \quad$ : Cukup Baik

4. $0 \% \leq \mathrm{NR} \leq 55 \% \quad$ : Cukup

Berdasarkan perhitungan persentase nilai perolehan dalam observasi kegiatan pembelajaran menggunakan metode jigsaw, maka diperoleh nilai sebesar 80\%. Taraf keberhasilan dari nilai yang diperoleh adalah baik, jadi kesimpulannya adalah kegiatan pembelajaran menggunakan metode jigsaw dinyatakan baik.

Tabel: Keterlaksanaan Kegiatan Pembelajaran dalam RPP

\begin{tabular}{|c|c|c|c|}
\hline \multirow{3}{*}{ Kegiatan } & \multirow{2}{*}{ Indikator Kegiatan } & \multicolumn{2}{|c|}{ Terlaksana } \\
\cline { 2 - 4 } & & $\begin{array}{c}\text { Ya } \\
\text { (Skor 1) }\end{array}$ & $\begin{array}{c}\text { Tidak } \\
\text { (Skor 2) }\end{array}$ \\
\hline Pendahuluan & 1 & 1 & \\
\cline { 2 - 4 } & 2 & 1 & \\
\cline { 2 - 4 } & 3 & 1 & \\
\cline { 2 - 4 } & 4 & 1 & \\
\cline { 2 - 4 } & 5 & 1 & \\
\cline { 2 - 4 } & 1 & 1 & \\
\cline { 2 - 4 } & 2 & 1 & \\
\cline { 2 - 4 } & 3 & 1 & \\
\cline { 2 - 4 } & 4 & 1 & \\
\cline { 2 - 4 } & 5 & 1 & \\
\cline { 2 - 4 } & 6 & 1 & \\
\hline Penuti & 7 & 1 & \\
\cline { 2 - 4 } & 1 & 1 & \\
\cline { 2 - 4 } & 2 & 1 & \\
\cline { 2 - 4 } & 3 & 1 & \\
\hline
\end{tabular}




\begin{tabular}{|c|c|c|c|}
\hline \multirow{3}{*}{ Kegiatan } & \multirow{3}{*}{ Indikator Kegiatan } & \multicolumn{2}{|c|}{ Terlaksana } \\
\cline { 2 - 4 } & $\begin{array}{c}\text { Ya } \\
\text { (Skor 1) }\end{array}$ & $\begin{array}{c}\text { Tidak } \\
\text { (Skor 2) }\end{array}$ \\
\cline { 2 - 4 } & 4 & 1 & \\
\cline { 2 - 4 } & 5 & 1 & \\
\cline { 2 - 4 } & 6 & 1 & - \\
\hline \multicolumn{2}{|c|}{ Jumlah Skor } & $\mathbf{1 8}$ & - \\
\hline
\end{tabular}

$$
\begin{array}{ll}
\text { Persentase Nilai Perolehan } & =\frac{\text { Julah Skor }}{\text { Skor Maksimal }} \times 100 \% \\
\text { Persentase Nilai Perolehan } & =\frac{18}{18} \times 100 \% \\
=100 \% &
\end{array}
$$

Berdasarkan perhitungan persentase nilai peolehan keterlaksanaan kegiatan pembelajaran dalam RPP, diperoleh nilai sebesar 100\%. Taraf keberhasilan dari nilai yang diperoleh adalah sangat baik. Artinya kegiatan pembelajaran dengan menggunakan metode jigsaw terlaksana sangat baik.

\section{Data Hasil Tes}

Guru mengajukan pertanyaan kepada siswa berkaitan dengan materi meyakini kitab-kitab Allah dan mencintai Al-Qur'an untuk mengetahui pengetahuan awal yang dimiliki siswa. Selanjutnya guru melakukan pre-test kepada siswa dengan memberikan teks soal. Hasil dari nilai pre-test siswa dapat dilihat pada tabel berikut.

Tabel: Nilai Hasil Pre-Test

\begin{tabular}{|l|l|c|c|c|}
\hline No. & Nama Siswa & Nilai Pre-test & KKM & Keterangan \\
\hline 1. & A & 45 & 75 & Tidak Tuntas \\
\hline 2. & B & 75 & 75 & Tuntas \\
\hline 3. & C & 45 & 75 & Tidak Tuntas \\
\hline 4. & D & 60 & 75 & Tidak Tuntas \\
\hline 5. & E & 70 & 75 & Tidak Tuntas \\
\hline 6. & F & 50 & 75 & Tidak Tuntas \\
\hline 7. & G & 75 & 75 & Tuntas \\
\hline 8. & H & 65 & 75 & Tidak Tuntas \\
\hline 9. & I & 70 & 75 & Tidak Tuntas \\
\hline 10. & J & 50 & 75 & Tidak Tuntas \\
\hline 11. & K & 55 & 75 & Tidak Tuntas \\
\hline 12. & L & 65 & 75 & Tidak Tuntas \\
\hline 13. & M & 80 & 75 & Tuntas \\
\hline 14. & N & 60 & 75 & Tidak Tuntas \\
\hline
\end{tabular}


Pengaruh Metode Cooperative Type Jigsaw Terhadap Peningkatan Hasil Belajar Siswa Mata Pelajaran Pendidikan Agama Islam

\begin{tabular}{|l|l|c|c|c|}
\hline No. & Nama Siswa & Nilai Pre-test & KKM & Keterangan \\
\hline 15. & $\mathrm{O}$ & 70 & 75 & Tidak Tuntas \\
\hline 16. & $\mathrm{P}$ & 50 & 75 & Tidak Tuntas \\
\hline 17. & $\mathrm{Q}$ & 85 & 75 & Tuntas \\
\hline 18. & $\mathrm{R}$ & 55 & 75 & Tidak Tuntas \\
\hline 19. & $\mathrm{~S}$ & 20 & 75 & Tidak Tuntas \\
\hline 20. & $\mathrm{~T}$ & 40 & 75 & Tidak Tuntas \\
\hline 21. & $\mathrm{U}$ & 65 & 75 & Tidak Tuntas \\
\hline 22. & $\mathrm{~V}$ & 75 & 75 & Tuntas \\
\hline 23. & $\mathrm{~W}$ & 70 & 75 & Tidak Tuntas \\
\hline 24. & $\mathrm{X}$ & 75 & 75 & Tuntas \\
\hline 25. & $\mathrm{Y}$ & 80 & 75 & Tuntas \\
\hline Jumlah & $\mathbf{1 5 5 0}$ & & \\
\hline Rata-Rata & $\mathbf{6 2}$ & & $\mathbf{7}(\mathbf{2 8 \% )}$ \\
\hline \multicolumn{2}{l|}{ Tuntas } \\
\hline \multicolumn{2}{l|}{ Tidak Tuntas } & & & $\mathbf{1 3}(\mathbf{7 2 \% )}$ \\
\hline
\end{tabular}

Dari hasil di atas terlihat bahwa siswa yang tuntas dalam belajarnya hanya 7 anak dengan persentase $28 \%$ dan siswa yang belum tuntas sebanyak 13 anak dengan persentase $72 \%$. Hal ini disebabkan karena siswa belum banyak menguasai materi meyakini kitab-kitab Allah dan mencintai Al-Qur'an, dan juga belum diterapkan metode pembelajaran Cooperative Type Jigsaw

Selanjutnya, dilakukan post-test pada tanggal 26 Agustus 2019. Pada awal pembelajaran guru memberikan materi dengan menggunakan metode jigsaw. Dimana siswa dikelompokkan berpasangan dengan teman sebangkunya untuk menyelesaikan masalah setelah materi disampaikan oleh guru, kemudian siswa memaparkan hasil diskusi dengan teman sebangkunya ke depan kelas untuk didiskusikan lagi bersama-sama.

Setelah semua selesai, guru memberikan post-test kepada siswa dengan memberikan lembar soal. Dari hasil data nilai post-test siswa dapat dilihat pada Tabel berikut.

Tabel: Nilai Hasil Post-Test

\begin{tabular}{|l|l|c|c|c|}
\hline No. & Nama Siswa & Nilai Post-test & KKM & Keterangan \\
\hline 1. & A & 65 & 75 & Tidak Tuntas \\
\hline 2. & B & 90 & 75 & Tuntas \\
\hline 3. & C & 65 & 75 & Tidak Tuntas \\
\hline 4. & D & 75 & 75 & Tuntas \\
\hline 5. & E & 75 & 75 & Tuntas \\
\hline 6. & F & 85 & 75 & Tuntas \\
\hline 7. & G & 85 & 75 & Tuntas \\
\hline
\end{tabular}




\begin{tabular}{|l|l|c|c|c|}
\hline No. & Nama Siswa & Nilai Post-test & KKM & Keterangan \\
\hline 8. & H & 65 & 75 & Tidak Tuntas \\
\hline 9. & I & 80 & 75 & Tuntas \\
\hline 10. & J & 75 & 75 & Tuntas \\
\hline 11. & K & 75 & 75 & Tuntas \\
\hline 12. & L & 75 & 75 & Tuntas \\
\hline 13. & M & 95 & 75 & Tuntas \\
\hline 14. & N & 65 & 75 & Tidak Tuntas \\
\hline 15. & O & 85 & 75 & Tuntas \\
\hline 16. & P & 70 & 75 & Tidak Tuntas \\
\hline 17. & Q & 90 & 75 & Tuntas \\
\hline 18. & R & 80 & 75 & Tuntas \\
\hline 19. & S & 40 & 75 & Tidak Tuntas \\
\hline 20. & T & 60 & 75 & Tidak Tuntas \\
\hline 21. & U & 90 & 75 & Tuntas \\
\hline 22. & V & 80 & 75 & Tuntas \\
\hline 23. & W & 80 & 75 & Tuntas \\
\hline 24. & X & 80 & 75 & Tuntas \\
\hline 25. & Y & 90 & 75 & Tuntas \\
\hline Jumlah & $\mathbf{1 9 1 5}$ & & \\
\hline Rata-Rata & $\mathbf{7 6 , 6}$ & & $\mathbf{1 7 ( 6 8 \% )}$ \\
\hline Tuntas & & & $\mathbf{8}$ (32\%) \\
\hline Tidak Tuntas & & & \\
\hline
\end{tabular}

Dari Tabel data nilai di atas dapat diketahui siswa yang tuntas dalam belajarnya berjumlah 17 siswa dengan persentase $68 \%$ dan siswa yang tidak tuntas sebanyak 8 siswa dengan persentase $32 \%$. Jika dibandingkan dengan nilai rata-rata Pre-Test sebelum pembelajaran menggunakan metode jigsaw, nilai rata-rata Post-Test lebih tinggi. Artinya terdapat peningkatan hasil belajar Pendidikan Agama Islam kelas V di MI Muhammadiyah 09 Kranji Lamongan.

\section{Hasil Analisis Data}

\section{Uji Instrumen}

\section{a. Uji Validitas}

Uji validitas soal dilakukan dengan menggunakan bantuan Software Microsoft Excel. Uji validitas yang peneliti gunakan adalah rumus korelasi product moment $\left(\mathrm{r}_{\mathrm{xy}}\right)$. Dari hasil perhitungan korelasi product moment dengan taraf signifikansi $\alpha=0,05$ diperoleh indeks $\mathrm{r}_{\text {tabel }}=0,3120$. Berdasarkan hasil perhitungan uji validitas dari 20 soal yang telah diuji cobakan dan dikonsultasikan dengan nilai $r_{\text {tabel }}$ diperoleh total seluruhnya valid. Hal ini 
Pengaruh Metode Cooperative Type Jigsaw Terhadap Peningkatan Hasil Belajar Siswa Mata Pelajaran Pendidikan Agama Islam

sesuai dengan kriteria ketentuan bahwa jika $r_{\text {hitung }}>r_{\text {tabel }}$ maka data tersebut dikatakan valid.

Tabel: Hasil Uji Validitas Soal Preetest

\begin{tabular}{|c|c|c|c|}
\hline No. Soal & $\mathbf{r}_{\text {tabel }}$ & $\mathbf{r}_{\text {hitung }}$ & Ket. \\
\hline 1 & 0,3120 & 0,4512 & Valid \\
\hline 2 & 0,3120 & 0,3676 & Valid \\
\hline 3 & 0,3120 & 0,3733 & Valid \\
\hline 4 & 0,3120 & 0,3447 & Valid \\
\hline 5 & 0,3120 & 0,3250 & Valid \\
\hline 6 & 0,3120 & 0,3664 & Valid \\
\hline 7 & 0,3120 & 0,3940 & Valid \\
\hline 8 & 0,3120 & 0,3798 & Valid \\
\hline 9 & 0,3120 & 0,3955 & Valid \\
\hline 10 & 0,3120 & 0,4487 & Valid \\
\hline 11 & 0,3120 & 0,3398 & Valid \\
\hline 12 & 0,3120 & 0,3258 & Valid \\
\hline 13 & 0,3120 & 0,3276 & Valid \\
\hline 14 & 0,3120 & 0,4448 & Valid \\
\hline 15 & 0,3120 & 0,3841 & Valid \\
\hline 16 & 0,3120 & 0,3417 & Valid \\
\hline 17 & 0,3120 & 0,3308 & Valid \\
\hline 18 & 0,3120 & 0,3940 & Valid \\
\hline 19 & 0,3120 & 0,4768 & Valid \\
\hline 20 & 0,3120 & 0,3250 & Valid \\
\hline & & &
\end{tabular}

Tabel: Hasil Uji Validitas Soal Posttest

\begin{tabular}{|c|c|c|c|}
\hline No. Soal & $\mathbf{r}_{\text {tabel }}$ & $\mathbf{r}_{\text {hitung }}$ & Ket. \\
\hline 1 & 0,3120 & 0,4526 & Valid \\
\hline 2 & 0,3120 & 0,3447 & Valid \\
\hline 3 & 0,3120 & 0,4371 & Valid \\
\hline 4 & 0,3120 & 0,3937 & Valid \\
\hline 5 & 0,3120 & 0,4124 & Valid \\
\hline 6 & 0,3120 & 0,3909 & Valid \\
\hline 7 & 0,3120 & 0,4989 & Valid \\
\hline 8 & 0,3120 & 0,5009 & Valid \\
\hline 9 & 0,3120 & 0,4681 & Valid \\
\hline 10 & 0,3120 & 0,4216 & Valid \\
\hline 11 & 0,3120 & 0,4388 & Valid \\
\hline 12 & 0,3120 & 0,4238 & Valid \\
\hline 13 & 0,3120 & 0,3409 & Valid \\
\hline 14 & 0,3120 & 0,3876 & Valid \\
\hline 15 & 0,3120 & 0,3737 & Valid \\
\hline
\end{tabular}




\begin{tabular}{|c|c|c|c|}
\hline No. Soal & $\mathbf{r}_{\text {tabel }}$ & $\mathbf{r}_{\text {hitung }}$ & Ket. \\
\hline 16 & 0,3120 & 0,3900 & Valid \\
\hline 17 & 0,3120 & 0,4442 & Valid \\
\hline 18 & 0,3120 & 0,4238 & Valid \\
\hline 19 & 0,3120 & 0,4526 & Valid \\
\hline 20 & 0,3120 & 0,3787 & Valid \\
\hline
\end{tabular}

\section{Pengujian Prasyarat Analisis Data}

Berdasarkan hasil penelitian yang telah didapat, maka data akan diolah dengan uji hipotesis menggunakan bantuan komputer program SPSS versi 20. Namun sebelumnya, terlebih dahulu akan dilakukan pengujian prasyarat analisis data, yaitu dengan uji normalitas dan uji homogenitas.

\section{a. Uji Normalitas}

Uji normalitas dilakukan dengan menggunakan rumus One Sample KS yang dilakukan dengan kaidah Asymp Sig atau nilai P. Pada penelitian ini, uji normalitas dilakukan terhadap skor pre-test dan skor post-test . proses perhitungan normalitas ini menggunakan bantuan software SPSS versi 20 untuk mengetahui sebaran data berdistribusi normal atau tidak. Sebuah syarat data berdistribusi normal:

1) apabila nilai signifikansi yang diperoleh dari hasil perhitungan lebih besar dari tingkat alpha $5 \%$ (sig. (2-tailed) >0,05).

2) Jika nilai signifikansi yang diperoleh dari hasil perhitungan lebih kecil dari tingka alpha $5 \%$ (sig. $(2$-tiled) $<0,05)$, maka data tersebut berdistribusi tidak normal.

Hasil uji normalitas sebaran data pre-test dan post-test dapat disajikan dalam Tabel berikut:

\section{Tabel:Hasil Uji Normalitas}

One-Sample Kolmogorov-Smirnov Test

\begin{tabular}{|c|c|c|c|}
\hline & & pretest & posttest \\
\hline$N$ & & 40 & 40 \\
\hline Normal Parameters ${ }^{a, b}$ & Mean & 62.13 & 74.25 \\
\hline & Std. Deviation & 18.112 & 18.382 \\
\hline & Absolute & .126 & .141 \\
\hline Most Extreme Differences & Positive & .103 & .104 \\
\hline & Negative & $-.136-$ & $-.141-$ \\
\hline Kolmogorov-Smirnov Z & & .863 & .893 \\
\hline Asymp. Sig. (2-tailed) & & .446 & .402 \\
\hline
\end{tabular}

a. Test distribution is Normal.

b. Calculated from data. 
Berdasarkan tabel di atas, dapat diketahui bahwa data pre-test memperoleh sig (2-tailed) sebesar 0,446 dan data post-test memperoleh sig (2-tailed) sebesar 0,402. Hal tersebut menunjukkan bahwa data tersebut berdistribusi normal.

\section{b. Uji Homogenitas}

Uji homogenitas dilakukan untuk mengetahui apakah kedua data memiliki varian yang sama atau tidak. Uji homogenitas dilakukan terhadap dua data, yaitu hasil pre-test dan post-test dengan ketentuan jika nilai signifikansi hitung lebih besar dari taraf signifikansi $0,05(5 \%)$ maka skor hasil tes tersebut tidak memiliki perbedaan varian atau homogen. Pengujian homogenitas peneliti menggunakan software SPSS 20 dengan Test of Homogenity of Variance. Hasil perhitungan uji homogenitas dapat dilihat pada tabel berikut:

\begin{tabular}{|c|c|c|c|}
\hline Levene Statistic & df1 & $\mathrm{df} 2$ & Sig. \\
\hline 2.116 & 9 & 27 & .064 \\
\hline
\end{tabular}

Berdasarkan data di atas, dapat diketahu bahwa kedua data memperoleh sig (2-tailed) sebesar 0,064 maka dapat disipulkan bahwa data pre-test dan post-test memiliki varian yang sama atau homogen.

\section{Pengujian Hipotesis}

\section{a. Uji Paired Sample T-test}

Setelah melakukan perhitungan uji prasyarat analisis data yaitu uji normalitas dan uji homogenitas dengan hasil perhitungan hasil data yang diperoleh merupakan data yang berdistribusi normal dan homogen, maka langkah selanjutnya peneliti dapat melakukan uji hipotesis yaitu uji Paired Sample T-test, dengan hasil sebagai berikut:

\section{Tabel: Hasil Uji Paired Sample T-test \\ Paired Samples Test}

\begin{tabular}{|l|r|r|r|r|r|r|r|}
\hline & \multicolumn{4}{|c|}{ Paired Differences } & t & df & Sig. (2- \\
tailed)
\end{tabular}

Dari hasil perhitungan di atas, nilai signifikansi (2-tailed) dari kasus ini adalah 0,000 (p < 0,05). Berdasarkan pedoman keputusan berdasarkan nilai probabelitas dapat ditarik 


\section{Chotibuddin}

kesimpulan bahwa terdapat pengaruh metode jigsaw terhadap hasil belajar siswa mata pelajaran Pendidikan Agama Islam di kelas V MI Muhammadiyah 09 Kranji .

\section{b. Uji Corelasi Product Moment}

Berdasarkan uji prasyarat analisis statistik, diperoleh bahwa data berdistribusi normal dan homogen. Untuk mengukur keeratan hubungan antara variabel X (penggunaan metode jigsaw) dengan variabel Y (hasil belajar Pendidikan Agama Islam) menggunakan uji korelasi product moment dengan bantuan software SPSS 20. Hasil perhitungan uji hipotesis dapat dilihat pada tabel berikut:

Tabel: Hasil Uji Korelasi Product Moment Correlations

\begin{tabular}{|c|c|c|c|}
\hline & & $X$ & y \\
\hline \multirow[t]{3}{*}{$x$} & Pearson Correlation & 1 & $.832^{*}$ \\
\hline & Sig. (2-tailed) & & .000 \\
\hline & $\mathrm{N}$ & 25 & 25 \\
\hline \multirow[t]{3}{*}{ y } & Pearson Correlation & $.832^{n}$ & 1 \\
\hline & Sig. (2-tailed) & .000 & \\
\hline & $\mathrm{N}$ & 25 & 25 \\
\hline
\end{tabular}

Tabel: Pedoman Untuk Memberikan Interpretasi Koefisien Korelasi

\begin{tabular}{|c|c|}
\hline Interval Koefisien & Tingkat Hubungan \\
\hline $0,00-0,199$ & Sangat Rendah \\
$0,20-0,399$ & Rendah \\
$0,40-0,599$ & Sedang \\
$0,60-0,799$ & Kuat \\
$0,80-1,000$ & Sangat Kuat \\
\hline
\end{tabular}

Sumber : Sugiyono (2017: p.257)

Interpretasi output SPSS 20 pada tabel korelasi, diperoleh harga koefisien korelasi sebesar 0,823 dengan Sigifikasi sebesar 0,000. Berdasarkan pedoman tabel 4.16 di atas dapat dinyatakan bahwa korelasi antara variabel $\mathrm{X}$ dan variabel $\mathrm{Y}$ tergolong sangat kuat. Dari data tersebut maka dapat dilakukan pengujian hipotesis dengan membandingkan taraf signifikansi (p-value) dengan galatnya.

Jika signifikansi > 0,05, maka $\mathrm{H}_{0}$ diterima

Jika signifikansi $<0,05$, maka $\mathrm{H}_{0}$ ditolak 
Pada kasus ini terlihat koefisien korelasi adalah 0,823 dengan signifikansi 0,000. Karena signifikansinya $<0,05$, maka $\mathrm{H}_{0}$ ditolak dan $\mathrm{H}_{\mathrm{a}}$ diterima. Artinya ada hubungan yang signifikansi antara penggunaan metode jigsaw terhadap hasil belajar Pendidikan Agama Islam.

Koefisien korelasi hasil analisis korelasi product moment dengan $\mathrm{r}$ tabel.

Pengujian:

Jika $\mathrm{r}$ hitung $>\mathrm{r}$ tabel, maka $\mathrm{H}_{0}$ ditolak

Jika $\mathrm{r}$ hitung < $\mathrm{r}$ tabel, maka $\mathrm{H}_{0}$ diterima

Dengan taraf kepercayaan 0,05 (5\%), maka dapat diperoleh harga $r$ tabel sebesar 0,412. Ternyata harga $r$ hitung lebih besar dari pada $r$ tabel $(0,823>0,412)$, sehingga $\mathrm{H}_{0}$ ditolak dan $\mathrm{H}_{\mathrm{a}}$ diterima. Artinya ada hubungan yang signifikansi antara penggunaan metode jigsaw terhadap hasil belajar Pendidikan Agama Islam. Data dan harga koefisien yang diperoleh mencerminkan keadaan populasi. Berdasarkan hasil koefisien tersebut juga dapat dipahami bahwa korelasinya bersifat positif.

\section{Kesimpulan}

Berdasarkan hasil penelitian dan pembahasan tentang "Pengaruh metode Cooperative Type jigsaw Terhadap Penngkatan Hasil Belajar Siswa Mata Pelajaran Pendidikan Agama Islam di Kelas V MI Muhammadiyah 09 Kranji Lamongan Tahun Pelajaran 2019/2020” peneliti dapat mengambil kesimpulan sebagai berikut:

a. Perbedaan hasil belajar siswa sebelum dan sesudah menggunakan metode jigsawdapat dilihat dari rata-rata hasil pre-test dan post-test siswa. Dimana rata-rata nilai hasil pre-test adalah 62,00 sedangkan rata-rata nilai hasil post-test adalah 76.60. Dari data tersebut dapat dilihat bahwa nilai hasil pre-test lebih rendah dibandingkan dengan nilai post-test, sehingga dapat diartikan bahwa terdapat perbedaan hasil belajar siswa sebelum dan sesudah menggunakan metode jigsaw dalam proses pembelajaran.

b. Presentase dari kriteria ketuntasan dari nilai hasil pre-test adalah $28 \%$, sedangkan dari nilai hasil post-test adalah 68\%. Dari data tersebut sudah bisa diketahui bahwa menggunakan metode jigsaw dapat mempengaruhi hasil belajar siswa. Kemudian dari pengujian hipotesis yang menggunakan uji Corelasi Product Moment dan uji Paired Sample T-test dengan 


\section{Chotibuddin}

bantuan software SPSS 20 pada bagian sig (2-tailed) diketahui sebesar 0,000<0,05. Sebagaimana dasar pengambilan keputusan dalam uji Corelasi Product Moment dan pedoman keputusan berdasarkan nilai probabelitas dapat diambil kesimpulan bahwa $\mathrm{H}_{0}$ ditolak dan $\mathrm{H}_{\mathrm{a}}$ diterima. Artinya, metode jigsaw dapat mempengaruhi peningkatan hasil belajar Pendidikan Agama Islam kelas V di MI Muhammadiyah 09 Kranji Lamongan.

\section{Daftar Pustaka}

Abu Ahmadi dan W. Supriyono, 2004. Psikologi Belajar. Jakarta: PT Rineka Cipta

Agus Suprijono, 2015. Cooperative Learning. Yogyakarta: Pustaka Pelajar

Arikunto, 2006. Prosedur Penelitian Suatu Pendekatan Praktik. Jakarta: Rineka Karya.

Aris Shoimin, 2014. 68 Model Pembelajaran Inovatif dalam Kurikulum 2013. Yogyakarta: ARRUZZ MEDIA

Departemen Agama RI, 2004. Al-Qur'an dan Terjemahnya,. Jakarta: CV Penerbit J-Art Ngalim Purwanto, 2004. Prinsip-Prinsip dan Teknik Evaluasi Pengajaran. Bandung: Remaja Rosdakarya

Santoso, Subhan Adi, 2020. Media Pembelajaran Pendidikan Agama Islam Era Industri 4.0. Yogyakarta: Deepublish

Sugiyono, 2011. Metode Penelitian Kuantitatif Kualitatif danR\&D. Bandung: Alfabeta

Undang-Undang No. 20 Tahun 2003. 2009. Tentang Sistem Pendidikan Nasional. Bandung: Fokus Media

Yana Wardhana, 2010. Teori Belajar dan Mengajar. Bandung: PT Pribumi Mekar

Zainal Aqib dan A. Murtadlo, 2016. Kumpulan Metode Pembelajaran. Bandung: Penerbit Satunusa 